\title{
Nære møter - fjerne liv
}

\section{Torsten Risør}

Praktiserende læge og studieplanchef, UiT Norges arktiske universitet, Tromsø torsten.risor@uit.no

Risør, T. (2014). Nære møter - fjerne liv. Tidsskrift for Forskning i Sygdom og Samfund, nr. 21, 15-17

\section{Velkommen til legekontoret:}

Mandag kl. 10. Gunbjørg er 30 år og samfunnsviter. Hun har vært på kontoret et par ganger i det siste: Håndeksem og gynekologisk sjekk. Nå har hun utslett i ansiktet. «Har du gjort deg noen tanker om hva det kan være?», spør jeg. «Ja,» sier hun: «Jeg har jo lest litt på nettet.»

Her starter frustrasjonene i legens hode. Pasienter leser jo her og der og bruker apper og mobiltelefoner og hva vet jeg. Henter inn bøttevis av informasjon. Hvorfor kan de ikke bare roe seg litt ned?

«Og øh» fortsetter hun, «jeg synes jo det likner på det her perioral dermatitt». Jeg ser på ansiktet hennes og må innrømme at det har hun helt rett i. Jeg nikker bekreftende. «Og ja, så stod det at man kanskje kunne behandle det med antibiotika - Tetracyklin, forsto jeg.» Jeg nikker igjen. Det er helt rett. «Noen steder sto det krem og andre sa tabletter. Så jeg vet ikke ...»

Hva skulle jeg si? Pasienten har vurdert sine symptomer, søkt informasjon, fortolket den, gjort sine egne overveielser. Helt rett. Vi endte med å velge tablettbehandling. Jeg sjekket med Gunbjørg at hun ikke har planer om å bli gravid i det første, da Tetracyklin er skadelig for fosterutvikling. 
Men hvorfor ble jeg så frustrert da Gunbjørg sa hun hadde «lest litt på nettet.» Jeg hører ofte den samme frustrasjonen fra kolleger, som ikke liker at medier og ny teknologi gjør pasienter bekymret og gir dem mye å tenke på. Men samtidig er vel det en del av pasientens virkelighet, og som lege bør jeg vel strebe etter å la pasientens virkelighet komme til syne i møtet med meg? Slik at selv om våre liv er ulike, så kan vi møtes og nå en felles forståelse. Kanskje. Det er vel noe med å lytte, ta på alvor, bli forundret.

En uke senere. K1. 13. Johan er en ingeniør på 43, fra Tyskland. Han har en kronisk betennelsestilstand i tykktarmen, som kaldes colitis ulcerosa. Han får medisin og han gikk tidligere til kontroll hos en magetarm-spesialist. Han spør meg om han kan redusere litt på medisinen. Han har det bedre, synes han. Det er fristende å si ja og bli raskt ferdig. Men jeg har ikke så travelt og jeg liker å snakke med Johan: «Kan du ikke fortelle meg litt mer? Jeg er litt nysgjerrig på hvordan dette ser ut for deg? Det er jo en sykdom som viser seg svert forskjellig fra menneske til menneske.» Han ser overrasket ut. Starter litt forsiktig: «Jo, altså jeg fikk jo noen bivirkninger. Tror jeg. Altså, jeg leste jo litt på nettet om medisinen...»

Leste på nettet. Igjen. De sure oppstøtene er på vei, merker jeg, og pulsen går opp. Men jeg behersker meg: «Fant du noe som var nyttig?» Johan nikker: «Jo da. Både om medisinen, men også - jeg leste om noen forsøk med kost, og fant noen diskusjonsgrupper, hvor andre har prøvd noen ting med kosten. Jeg skrev til en av dem og fikk noen råd. Så det har jeg prøvd. Jeg syns det virker. Så det er det, at jeg kunne ha lyst å se om det holder seg, hvis vi tar vekk litt av medisinen.»

Jeg nikker. Det høres fornuftig ut. Vi leger vet fortsatt lite om årsakene til sykdommen og selv om vi har medisin, så er det mest symptombehandling og utsetter det tidspunktet, hvor det kan bli nødvendig med en tarm-operasjon og kanskje en pose på magen. Jeg vover å slippe autoriteten et øyeblikk: «Johan, faktisk er det jo en sykdom som vi leger vet lite om årsakene til. Men inn imellom skjer det pasienter selv finner noe som virker for dem. Det var tilfeldig det viste seg røyking noen ganger kan dempe symptomene. Jeg vet en dansk lege fant at sporstoffet titan kan ha effekt. Tilfeldighet og gode ideer kan være veien frem. Her er dine erfaringer viktige. Kanskje en løsning viser seg, som gjør det lettere å leve med». Johan så overrasket ut igjen: «Det er der ikke noen der har sagt før». Vi snakket litt videre, la en plan, fant en ny time til å følge opp.

Det er sjeldent tid til å reflektere i den travle hverdagen på legekontoret. Men her er det likevel en del å tenke over. Jeg må ta meg tiden. Det er ofte skrevet om at pasienter i dag er mer "krevende". Det tales om den "informerte pasienten", som er "forbruker" av helseinformasjon. Jeg hører leger som er bekymret over utvik- 
lingen. De tenker det er skadelig for lege-pasient forholdet; at det gjør pasienter unødig bekymret. I møtet med Gunbjørg og Johan er det ganske riktig unødig bekymring. Men det er ikke pasienten som har den. Her må vi leger nokk turde ta et kritisk blikk på oss selv også.

Vi lærer lite om filosofi og antropologi på legeutdanningen, men kanskje vi burde det. For å kunne forstå hva kunnskap er og skapes og hvordan vi mennesker bruker den kunnskapen i hverdagen. Vi er alle del av nettverk - sosiale og digitale. Og hvor interaksjon med andre blir del av vår egen forståelse, som vi igjen kan bringe videre til andre. Når jeg møter Gunbjørg og Johan får jeg lov å være del av deres nettverk - og de får kontakt med mitt. Når det går godt, er det fruktbart for begge parter. Den enkeltes nett trekker langt omkring i tid og rom og i den forstand er Gunbjørgs og Johans liv fjerne for meg. Jeg kan aldri lære å forstå disse fjerne liv og deres kompleksitet, som de gjør det. Men jeg kan se at de nye kommunikasjons-kanaler som mennesker har skapt har betydning i deres liv. Og jeg kan se at jeg må ta den del av deres liv på alvor, akkurat som jeg tar alt det annet på alvor. Så kan det bli mulig å ha nære møter, selv om avstanden fra mitt liv til deres er stor.

Høres det pompøst ut? Kanskje det. Men jeg synes det hjelper meg til å løfte meg litt ut av de konkrete møtene med mennesker og tenke over hva det er som skjer. Så jeg kan gå tilbake og lytte mer og gi mer - og unngå sure oppstøt og hjertebank. Jeg tror bekymringen over pasienter som er "informert" er en bekymring for forandring; forandring av pasientens rolle - og forandring av legens rolle. Forandring kan føre til uro. Jeg vet i det minste det gir uro hos meg, når hverdagens rutiner brytes. Leger er dedikert til deres arbeide: Vi arbeider ikke som leger. Vi er leger. Nå skjer det ting som skaper forandring i vårt arbeid og da blir vi i tvil om hvem vi er. Det er den vanskeligste forandring, jeg vet om.

Og midt i denne uro over meg selv og hvem jeg er, kommer jeg på at det fortsatt er fullt av pasienter på venterommet. De har ikke stoppet å komme selv om de kan finne informasjon andre steder. Legen blir åpenbart ikke overflødig, selv om medisinsk kunnskap er fritt tilgjengelig på nett? Men hva blir da min rolle og min oppgave? Mine pasienter lever liv som er fjerne for meg, men kan vi ha nære og givende møter likevel? Jeg går ut for å invitere neste pasient innenfor. Dette skal bli spennende å utforske. 